\title{
Preparation of Spherical Fine Particles of Yttrium/Iron Composite by Precipitation from Homogeneous Solution Containing Urea
}

\author{
by Yoshihiro NISHISU ${ }^{1}$ and Mikio KOBAYASHI ${ }^{2}$
}

1. National Institute for Resources and Environment, Onogawa, Tsukuba 305-8569

\begin{abstract}
Fine composite particles containing yttrium and iron were prepared from homogeneous solution using urea as a precipitant generator. The ratio of yttrium to iron in the precipitate could be controlled by adjusting the concentration of the starting materials in the initial solution. These composite particles were considered to be amorphous. Shapes and morphology of the precipitated particles were influenced by the difference of the reaction conditions. Particles obtained from the solution containing $1.88 \mathrm{mmol} \mathrm{dm}{ }^{-3} \mathrm{FeCl}_{3} \cdot 6 \mathrm{H}_{2} \mathrm{O}, 3.13 \mathrm{mmol}$ $\mathrm{dm}^{-3} \mathrm{YCl}_{3} \cdot 6 \mathrm{H}_{2} \mathrm{O}$ and $500 \mathrm{mmol} \mathrm{\textrm {dm } ^ { - 3 }}$ urea at $97{ }^{\circ} \mathrm{C}$ were almost spherical and mono-dispersed. Particles precipitated on the condition as mentioned above converted from amorphous into monophasic garnet $\left(\mathrm{Y}_{3} \mathrm{~F}_{5} \mathrm{O}_{12}\right)$ by calcining at $1,200^{\circ} \mathrm{C}$ for 5 hours. After calcination, particle changed its color from brown to medium olive and indicated marked magnetic character.
\end{abstract}

KEY WORDS : Precipitation from Homogeneous Solution, Spherical Fine Composite Particle, $\mathrm{Y}_{3} \mathrm{Fe}_{5} \mathrm{O}_{12}$

\section{1. 緒}

複合酸化物などの多成分系で用いられることの多いレアアース 系の菜材は，出発材料の段階から精密な調製を必要とする場合が 多い。イットリウム-鉄-片ーネット（YIG）等のレアアースと鉄 とを安成分とする化合物は，磁性村料や，光アイソレータ1)等の 機能性材料として重要な素材で西る。一方，尿素を用いた均一沈 殿法 (Precipitation from Homogeneous Solution) は, 均一 な溶液から微粒子等の析山物を調製する方法で，均質で維密な沈 殿が得られることを特徽とし，また液相法の一般的な特長として 指摘さ机ているように，形状や成分の制御も比政的容易に可能て あると期待される2)3)。

著者らはこれまでに，尿素を沈殿敦発生試薬とする均…沈殿法 を用いて，単分散性に優れたユウロピウム（Eu）賦活イットリ ウム $(\mathrm{Y})$ 酸化物巣光体 $\left(\mathrm{Y}_{2} \mathrm{O}_{3}: \mathrm{Eu}\right)$ の前駆体となる多成分球状微 粒子の調製が可能であることを示した4)。既報では，異なる析出 特性の Y 制御可能であること，また成分比を変化させても粒度の均一性を 雜持できることなどを明らかにした。これらの結果から，液相法 が適用可能な他の多成分系紊材の調製にも，本法学適用して各素 材ごとに必要な微量成分や形状の制衙を可能とすることが期待さ れる。本報では，尿素を用いた均一沈殿法により，組成の制御が 重要であり，また様々な形状での使用が予想される YIGの前䞁

* 1999作 2 月 25 日受付 5 月 10 月受理

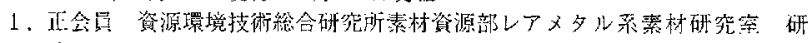
究具

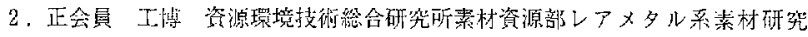
空 室度

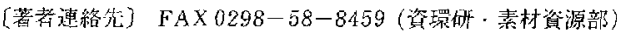

キーワード: 均一沈殿法, 複合球状微粒子, $\mathrm{Y}_{3} \mathrm{Fe}_{5} \mathrm{O}_{12}$
体上なる，鉄 $(\mathrm{Fe})$ およびレアアースであるイットリウム（Y) との複合微粒子の調製について検討を行ったので報出する。

\section{2. 実駼方 法}

\section{$2 \cdot 1$ 試料}

出発原料としては，塩化イットリウム六水利物 $\left(\mathrm{YCl}_{3} \cdot 6 \mathrm{H}_{2} \mathrm{O}\right)$ (和光純䒚(株)製，>99.9\%)，塩化鉄（泪）六水和物 $\left(\mathrm{FeCl}_{3} \cdot 6\right.$ $\mathrm{H}_{2} \mathrm{O}$ ）（同上），尿素（和光純薬(株)製，特級）を用いた。 $\mathrm{pH}$ 調 節は酸として塧酸（同上）を用いて行った。

\section{$2 \cdot 2$ 微粒子の調製方法}

$0.90 \mathrm{dm}^{3}$ の純水に所定量の試薬を加兄てから所完の $\mathrm{pH} に$ に調節 して調製した溶液を 24 時間程度静置し，この溶液を原液とした。 合成は原液を $97{ }^{\circ} \mathrm{C} に$ 加温して反応を生じさせることにより行っ た。合成中は, インペラにより摬找を行い, 還流冷却器を使用し て水蒸気の蒸発在防いた。加温を開始して加ら90 分経過後, 水 水を入れたウオータバスを用いて，溶液の温度を迅速に室温まで 喻却した。古実験系では，反応過程での所定の時間に，シリン ジを用いて反底中の溶液のサンプリングを行い，得られたサンプ ルは室温まで迅速に泠却した。溶液の $\mathrm{pH}$ は、いずれも室温まで 冷却した後に測定を行った。また反応終了後、室温まで冷却した 溶液は，遠心分離による上澄みの除去 $\rightarrow$ 純水添加 $\rightarrow$ 超音波に上 る再分散 $\rightarrow$ 遠心分離という操作を 4 度繰り返し，溶液に奬濁し ている反応により生成した微粒子を分離洗浄した。洗浄後の微粒 子は，速やかに2-プロパノールを分散媒として上記洗浄操作之 同様の操作を繰り返寸ことによって，分散媒を2-プロパノール に置換した。置換後は真空乾燥を行い，ある実験柔では，乾燥後 の微粒子の一部をマッフル炉を肺いて所定の温度により焼成した。

$2 \cdot 3$ 微粒子の評価方法

合成後の溶液中心溶存する金属イオン濃度を，誘導絬含プラズ 
Table 1 Experimental conditions and results.

\begin{tabular}{|c|c|c|c|c|c|c|c|c|}
\hline \multirow{2}{*}{$\begin{array}{l}\text { Experi- } \\
\text { mental }\end{array}$} & \multicolumn{3}{|c|}{$\begin{array}{l}\text { Concentration } \\
\left(10^{-3} \mathrm{~mol} / \mathrm{dm}^{3}\right)\end{array}$} & \multirow{2}{*}{$\begin{array}{c}\text { Initial } \\
\mathrm{pH}\end{array}$} & \multirow{2}{*}{$\begin{array}{l}\text { Reaction } \\
\text { temperature } \\
\left({ }^{\circ} \mathrm{C}\right)\end{array}$} & \multirow{2}{*}{$\begin{array}{c}\text { Reaction } \\
\text { time } \\
\text { (min) }\end{array}$} & \multirow{2}{*}{$\begin{array}{c}\text { Final } \\
\mathrm{pH}\end{array}$} & \multirow{2}{*}{$\begin{array}{l}\text { Precipitatio } \\
\text { ratio } \\
(\%)\end{array}$} \\
\hline & $\overline{\mathrm{YCl}} 3 \cdot 6 \mathrm{H}_{2} \mathrm{O}$ & $\mathrm{FeCl}_{3} \cdot 6 \mathrm{H}_{2} \mathrm{O}$ & Urea & & & & & \\
\hline$Y-1$ & 10.0 & 0 & 500 & 2.3 & 97 & 90 & 8.6 & $>99$ \\
\hline $\mathrm{F}-1$ & 0 & 10.0 & 500 & 2.3 & 97 & 90 & 8.5 & $>99$ \\
\hline$Y F-1$ & 2.00 & 8.00 & 500 & 2.3 & 97 & 90 & 8.8 & $>99$ \\
\hline$\overline{Y F}-2$ & 3.75 & 6.25 & 500 & 2.3 & 97 & 90 & 8.4 & $>99$ \\
\hline YF-3 & 6.00 & 4.00 & 500 & 2.3 & 97 & 90 & 8.7 & $>99$ \\
\hline$Y F-4$ & 8.00 & 2.00 & 500 & 2.3 & 97 & 90 & 8.5 & $>99$ \\
\hline$Y F-5$ & 9.90 & 0.10 & 500 & 2.3 & 97 & 90 & 8.7 & $>99$ \\
\hline YF-6 & 3.75 & 6.25 & 500 & 1.5 & 97 & 90 & 6.8 & $>99$ \\
\hline$Y F-7$ & 1.88 & 3.13 & 250 & 2.3 & 97 & 90 & 8.3 & $>99$ \\
\hline YF- 8 & 1.88 & 3.13 & 500 & 2.3 & 97 & 90 & 8.5 & $>99$ \\
\hline
\end{tabular}

マ発光分光分析装置（セイコー電子工業(株)製, SPS 4000）によ り測定した。また上澄みと原液との金属成分の濃度差から，新出 した金属成分量を求めた。この析出した金属成分量の，原液中の 金属成分量に対する百分率を析出率とした。

生成した微粒子については，個々の微粒子小のYと $\mathrm{Fe}$ との成 分比測定が困難であったため, 乾燥後の微粒子産物の少量を無作 為に採取して酸性水溶液中に溶解し，得られた水溶液の Y 拉よ び Fe 洹度を ICP 分析装置により測定し，この $\mathrm{Y} / \mathrm{Fe}$ 成分比を微 粒子の成分比とした。さらに示差熱 (DTA) 熱重量 (TG) 湘定 装置（七イコ一電子(株)製，SSC $5200 \mathrm{H}$ Disk Station, TG/ DTA 320）を用いて熱分析を行い，また焼成の前後で，透過型 電子顕微鏡（TEM)(Philips 製, C 30/STM)による観察と, 赤 外分光光度計（（株）日立製作所製 270-30 型）を用いて赤外吸収 スベクトル (IR スペクトル) の測定, X 線 (Cuk $\alpha)$ 回折装置 (理学霞気(株)製，ロータフレックスRU-300）を用いてX 線回 折パターン（XRDパターン）の測定老行った。

\section{3. 実験結果および考察}

\section{$3 \cdot 1$ 微粒子の生成}

Table 1 に本微粒子生成反灾の実験条件を示す。なお, 本実験 条件において加温中の溶液の温度を昇温誖 $97{ }^{\circ} \mathrm{C}$ 一定とし, 加温 を開始してから冷却するまでの時間を 90 分としたが，これらの

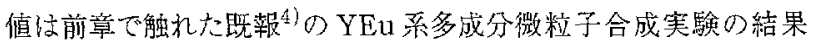
に基づき設定したものである。また Y-1，F-1，YF-1ー5につい ては，原液の金属成分浱度や初期 $\mathrm{pH}$ 等の他の条件も同様に設定 し，YEu系で単分散性に優れた球状微粒子が生成した場合と同 等の実験条件とした。

以上の実験条件下で，原夜に金属成分としてYのみを含む $\mathrm{Y}$ 1 では, 加温して $97{ }^{\circ} \mathrm{C} の 一$ 定值に保持してから約 3 分後に析出 を示方白濁が確認芑れた。Y-1で白濁が確認されてから後は, 濁 度が増加する以外には溶液の色等に変化は認施れなかった。原 液に金属成分として Feのみを合むF-1では，設定温度の97 ${ }^{\circ} \mathrm{C}$ に達する前の $70^{\circ} \mathrm{C}$ 前後の杽温過程で赤褐色の愳濁が生じ始め, 以後時間の経渦とともに濁度の堌加加確認された。原液に金属成 分として Y と Feの而成分を含む $\mathrm{YFe}$ 系 $(\mathrm{YF}-1 \sim 8)$ では, F-1 と同様に $97^{\circ} \mathrm{C}$ に達する以前の昇温過程で赤褐色の賏羁が確 認された。さらに $\mathrm{YFe}$ 系では, 設定温度の $97^{\circ} \mathrm{C}$ 一定值に保持し た後，溶液の懸濁色は徐々に赤みが薄れ黄褐色へと変化した。な

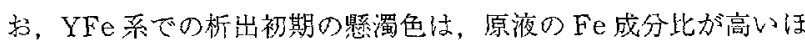
ど暗赤色が強く, 逆に Y 成分比が高いほど黄蝎色に近づく傾向 を示した。

$\mathrm{Y}-1 ， \mathrm{~F}-1$ 抢よび $\mathrm{Y} / \mathrm{Fe}$ 比が $\mathrm{YIG}$ 量諭比相当の YF-2 と $\mathrm{YF}-8$ の, 反応時問が $45,60,75,90$ 分の場合の $\mathrm{Y}$ 扔上び $\mathrm{Fe} の$ 析出率をFig. 1 に示す。いずれの場合も Feについては，99\%

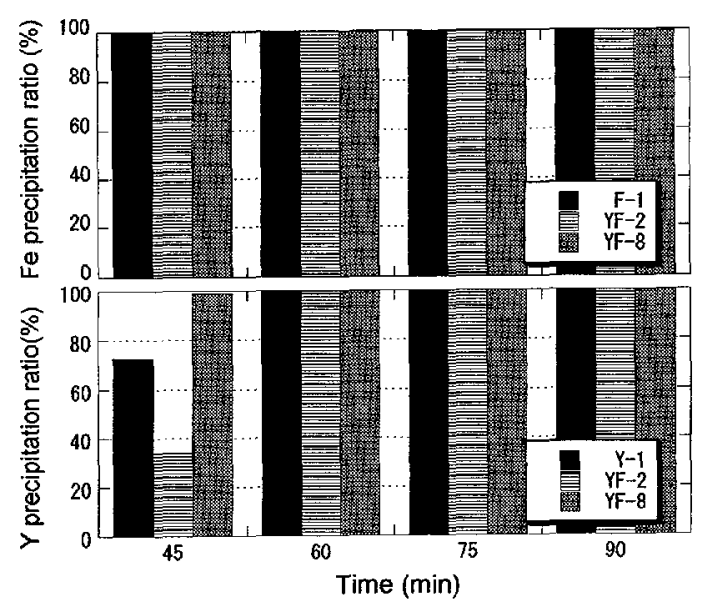

Fig. 1 The relationship between reaction time and precipitation ratio of $\mathrm{Y}$ and $\mathrm{Fe}$.

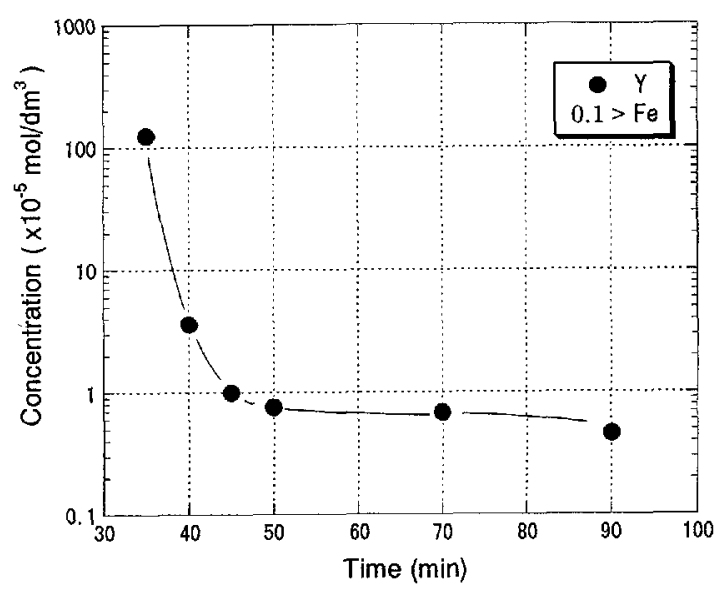

Fig. 2 Change in the concentration of metal ions on the reaction.

以上の析出率となった。Yについては，原液の金属成分濃度が 他と比較して 1/2のYF-8のみ 45 分の反応で $99 \%$ に達したが, Y-1 およよ゙YF-2では 45 分の反応でともに $80 \%$ 以下であった。 このことから，FeよりもYの析出の方が洋い傾向にあることが わかる。YIG 前駆体の合成過程を前提として均一性の観点から は、Yと $\mathrm{Ye}$ の析出が同時に生じた方が有利と考えられる。そこ で，Yの析出率が反応時間 45 分でも $99 \%$ に遼した YF-8につ いて，より詳細にサンプリング実験老行い検討した。Fig. 2 に は, YF-8の反応時間 $35 \sim 90$ 分の溶液中に溶存している未析出 の Y と Feの濃度（残留濃度）走示す。Fig. 2 に狲て反応時間 35 分の Y の残留濃度が Feに比較して著しく高く、YF-8におい 


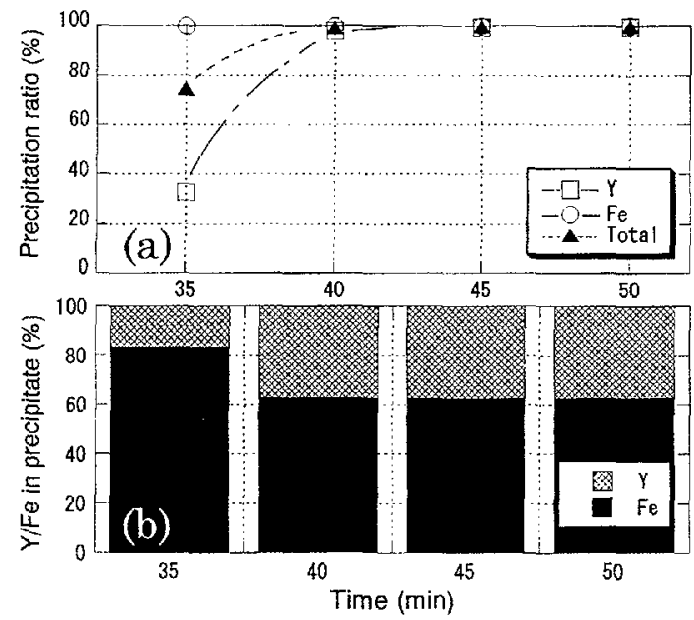

Fig. 3 Changes in (a)precipitation ratio of metal ions and (b) $\mathrm{Y} / \mathrm{Fe}$ in the precipitate on the reaction.

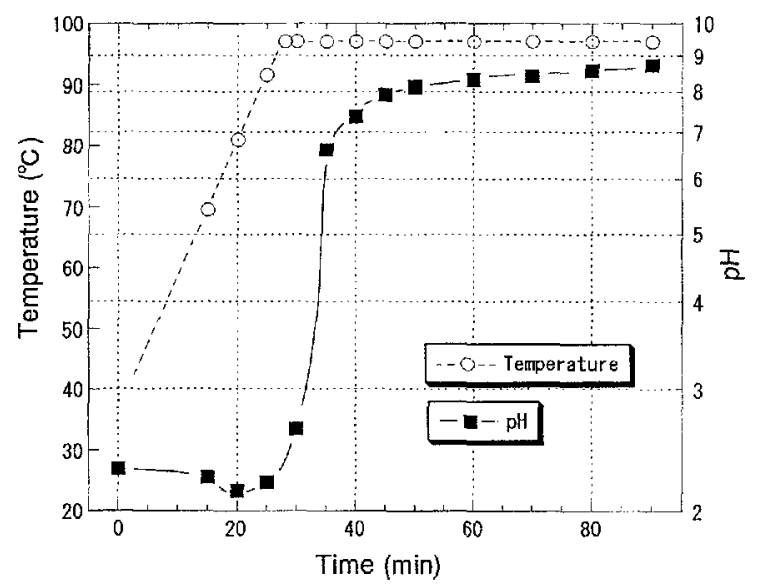

Fig. 4 The relationship between reaction temperature and $\mathrm{pH}$ change.

てもFeの析出がYよりも先に生じていたことがわかった。 Fig. 3(a)は，YF-8の反応時閒 35-50分のY执よび Feの析 出率を示したものである。Feは35分の段階ではほ $99 \%$ 以上の 析出率となったが、Yは33\%程度である。以徯時間の経過とと むに Yの析出率も增加し，45分で $99 \%$ 以上に達した。したが て得られた微粒子の $\mathrm{Y}$ と $\mathrm{Fe}$ 成分比は反心の経過とともに変化し, Fig. 3(b)に示されるように，反応初期の段階では比較的 Fe 成

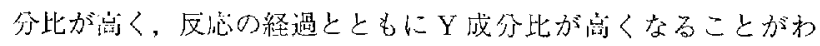
加た。

YF-8のサンプリング赛験での溶液の洫度および $\mathrm{pH} の$ 経時変 化をFig. 4 に示す。pH は，20 分前後で一度極小值を示し，溶 液の温度が $97^{\circ} \mathrm{C}$ に㵏した後の30４0分の間に著しく上昇した。 20 分前後での $\mathrm{pH}$ の蹪著な極小值は，本系では $\mathrm{Fe}$ を含む場命に のみ瑟められている。この現象は，松田ら放指摘しているよう に Fe 成分の加水分解に起网寸る上考之られる。その兴に見られ る $\mathrm{pH}$ の急激な上昇は, 次式の尿素の加水分解に起因卞ると考之 られる ${ }^{(0)-8)}$

$\left(\mathrm{NH}_{2}\right)_{2} \mathrm{CO}+3 \mathrm{H}_{2} \mathrm{O} \rightarrow 2 \mathrm{NH}_{4} \mathrm{OH}+\mathrm{CO}_{2}$

$\mathrm{Y}$ については, この尿美の加水分解で水溶液中に生成する水酸 化物イオン $\left(\mathrm{OH}^{-}\right)$および炭酸イオン $\left(\mathrm{CO}_{3}{ }^{2-}\right)$ 等と庈応して 析出を生ずると考えられる゙。

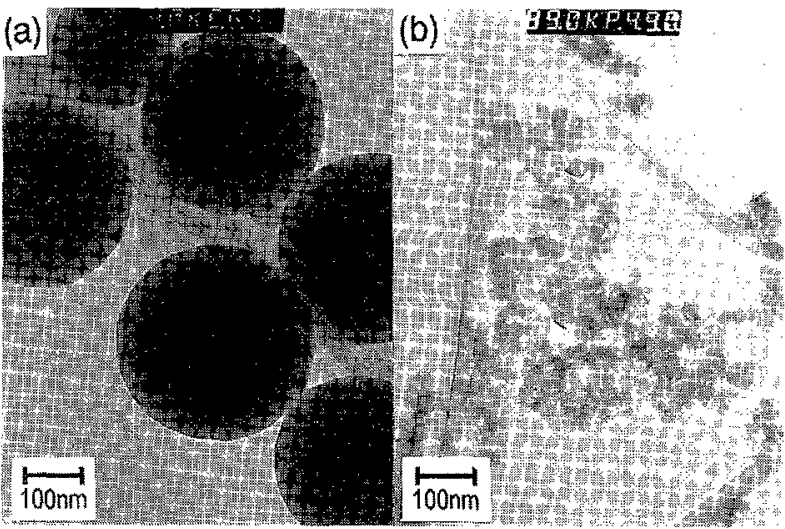

Fig. 5 The TEM photographs of the particles precipitated from (a) $\mathrm{Y}-1$ and (b) F-1.

以上から，本 $\mathrm{YFe}$ 柔では，析出の確認された初期の段階で Fe 成分の加水分解等に上る析出反応が生し，Yの析山反応と沙少 なからず時閒的なずれを生ずることがわかった。なお， Table 1 に示したと拉り，Y-1，F-1，YF-1ー8のいずれの場合も60 分 間の反心で $\mathrm{Y}, \mathrm{Fe}$ とも析出率は $99 \%$ 以上となった。

\section{$3 \cdot 2$ 微粒子の形状}

Y-1で生成した微椟子の TEM 写真をFig. 5 (a)に示す。金属 成分としてYのみ含をY-1では，既報)のと㧍り平均精徍 300 $\mathrm{nm}$ 程度の球状で笚分散性の良好な微粒子が生成した。Fig. 5 (b)

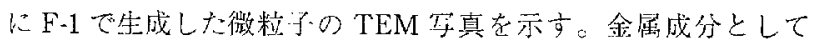
Feの及考含をF-1では, 一次粒子として粒径 $10 \mathrm{~nm}$ 以下の超微 粆子を含む，人きさの不均一な凝集性の微粒子が生成した。また F-1では，一次粒子よりも大きいが・次糔子の凝集物とは明らか に異なる菱形に近い形状の微粒子の生成が認められた。金属成分

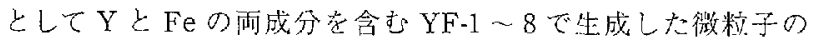

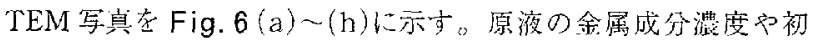

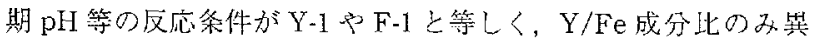

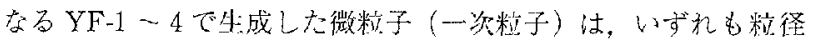
が数十 $\mathrm{nm}$ 程度で，F-1の一次粒子より明らかに大きいが Y-1に 比輍して著しく小さい（Fig. $6(\mathrm{a}) \sim(\mathrm{d}))$ 。寲集の程度も Y-1に 比較して大きいが，形状はF-1より明らかに均筫である。TEM 写真からはYF-1～80いずれの場合にも，F-1で生じた粒径 10 $\mathrm{nm}$ 以下の超微粒子や，Y-1で生じた粒径 $300 \mathrm{~nm}$ 程该の球状微 社子の混在は認められず，YとFeが相互に影響することなく完 全に独立して各多微校子学形成したとは桨光難い。しかし，原液 O Y $/ F$ C 成分比を $2 / 8(Y F-1)-8 / 2(Y F-4)$ 上変化させても $\mathrm{Y}-$ 1 と闰程优の球形性や大きさの均一性等は得ら机ず, 同等の反心

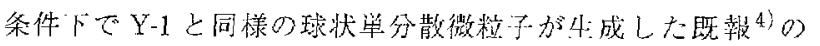
$\mathrm{YEu}$ 多成分系とは明らかに傾向が異なる。 $\mathrm{Y} / \mathrm{Fe}$ 成分比が $9.9 /$ 0.1 で他の条件が YF-1 - 4 上等しいYF-5では, 球形性は比較的 Y-1に近似しているが，一次粒子の大きさについてはYF-1－4 と同椂に Y-1に比べ著しく小さく，YFe系においてはFeの形態 に対する影暗の著しいことがわかる（Fig.6(e)）。羽用らは， 均一沈殿法によるイッテルビウム $(\mathrm{Yb})$ - 鉄ーガーネット粉体合 成の倹討に扔いて，Ybと $\mathrm{Fe}$ とが独立して一次精子を形成し， そ机らが凝集して二次校子孝形成し，一次粒了の大きさは成長の 過程を経ても顕著に変化しないと考察している9)。羽同らと同じ レアアースー鉄ーガーネットの系ではあっても，本 YFe系では 前述の結果から同様の複合過程は適忍し之ないと考えられる。

$\mathrm{Y} / \mathrm{Fe}$ 战分比のほ加, 微粒于の球形性, 大きさの均一性や分散 


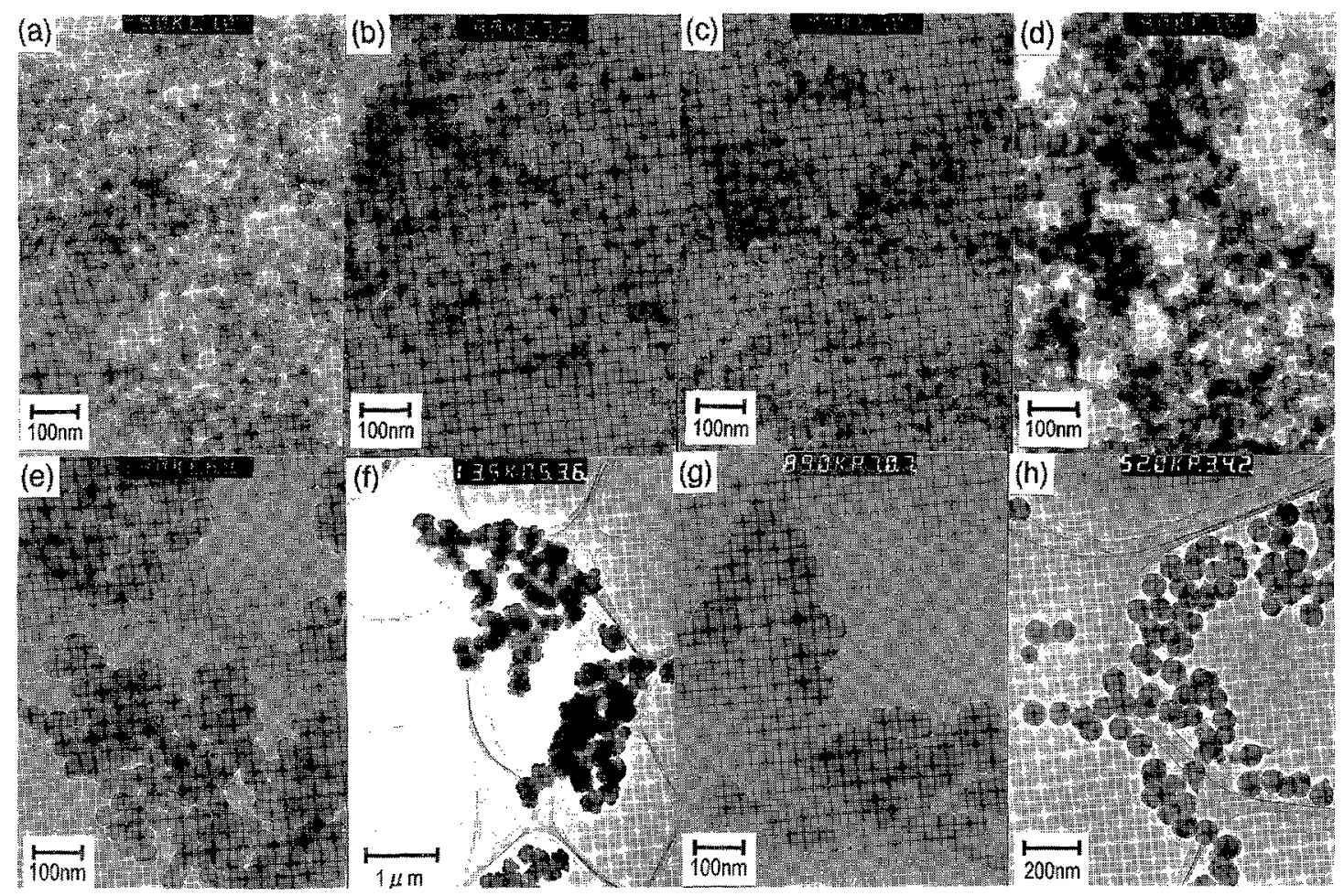

Fig. 6 The TEM photographs of the particles precipitated from (a)YF-1, (b) YF-2, (c)YF-3, (d)YF-4, (e)YF-5, (f) YF-6, (g)YF-7 and (h) YF-8.

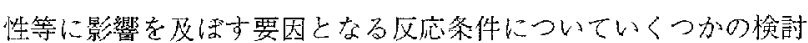
を行った。 YF-2 と原液の初期 $\mathrm{pH}$ のみが異なる YF-6では, YF2よりも大きいサブミクロンオーダの微粒子が生成した（Fig.6 (f)）。この微粒子は，同じサブミクロンオーダのY-1 で生成した 微粒子と比較して，表面の凹几が著しくまた凝集の程㜔が大きい など，一次粒子少㠜集して形成されたのではないかと推祭される 形状が認如られ。初期 $\mathrm{pH}$ 老低下させた場合，析出が生ずるた

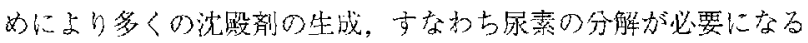
と推測され，この $\mathrm{pH}$ 条件の恙が形状の変化の一因にもなったと 推察される。一方，沈殿剂の比率が岕くな扎ば反対の効果が期待 される。YF-2 と比較して原液の金属成分の浱度が $1 / 2$ の Y - 8

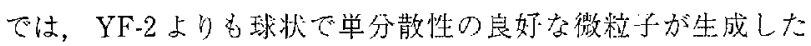
(Fig.6 (h)）。YF-8の球形性，大き导の均‥性や分散性（単分散 性) は，明ら加にY-1 の特性に近似するものと考之られる。こ の球形性や単分散性の间上は, 式(1)の反応で水溶液中に生成す る $\mathrm{OH}^{-} や \mathrm{CO}_{3}{ }^{2-}$ 等の沈殿剤の金属イオンに対する比率や倛給速 度が，相対的に堌加したことに起因方ると推察される。すなわち， 沈殿剂の供給量增加によって，析出過程で微粒子がより知特問に 生成するなど，析出過程に変化が生じ，そのことが影響を及はし たものと考えられる。前述のと扮り YF-2よりも YF-8の方が $\mathrm{Y}$ の析出が早く進行していることから，析出反机の速度等に影響が あったことは明らかである。Yの析出汢，前述のと拉り泪水分 解反応によって析出を生ずると考无的れる $\mathrm{Fe}$ よりも，式(1)で 生成する沈殿剂の生成量や生成速度等の大小による影響が影著で 支ると推察される。これらの要因が総じて, YF-2 と YF-6 およ びYF-8 との形状の差に現れたのではない外と推察される。

以上これまでの結舁から，本 YFe 乘の微䊉子形成の過程は， Y招上び $\mathrm{Fe}$ の备々独立した一次䊓子の形成と，一次精子の単純 な凝集から成る過程ではなく、Yと Fe とが相互に作用する一種 の複合化の過程であると推察される。またYFe 系においても， 適切に反応条件を制御方ることによって，生成する微粒子に高い

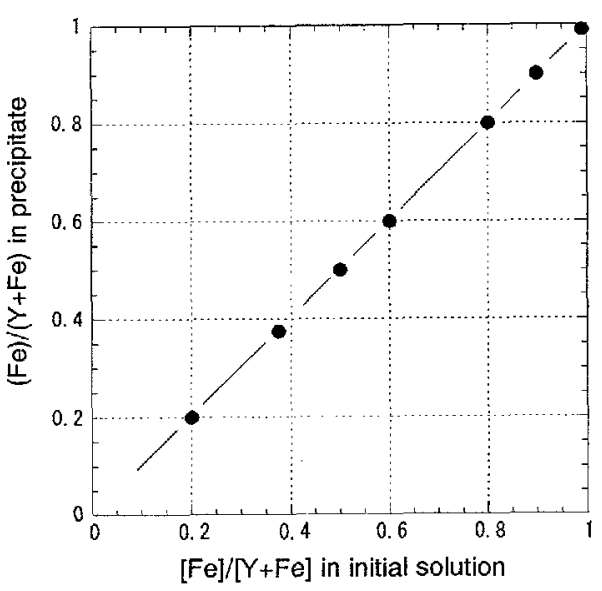

Fig. 7 The relationship between $\mathrm{Fe} /(\mathrm{Y}+\mathrm{Fe})$ in the precipitate and $[\mathrm{Fe}] /[\mathrm{Y}+\mathrm{Fe}]$ in the initial solution.

球形性，大きさの均一性や分散性が得られることが明らかたなっ た。

\section{$3 \cdot 3$ 微粒子の成分と構造}

本㴈で生成した $\mathrm{YFe}$ 系微粒子の $\mathrm{Y} / \mathrm{Fe}$ 成分比と原液の $\mathrm{Y} / \mathrm{Fe}$ 濃度比との関係を Fig. 7 に示寸。この結果より，原液濃度によっ て微精子の $\mathrm{Y} / \mathrm{Fe}$ 成分比を制御可能であることが劣かる。な枋， 以下の本節以降では, $\mathrm{Y}$ 系や $\mathrm{YEu}$ 系微粒子の成分等について検

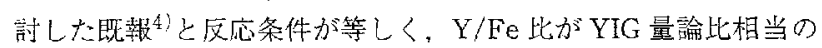
YF-2を索心に論ずる。

Fig. 8 には，YF-2で牛成した微粒子と，YF-2 と金属成分以 外の反応条件が等しいY-1 および F-1で生成した微粒子のIR ス ペクトルを示方。YF-2および金属成分としてYのみ含むY-1 ては, $\mathrm{CO}_{3}{ }^{2-}$ によると思われる吸取（1,600～1,350，880～860 $\left.\mathrm{cm}^{-1}\right)$ 抢よび $\mathrm{OH}^{-}$または $\mathrm{H}_{2} \mathrm{O}$ によると思われる吸取（3,500〜 


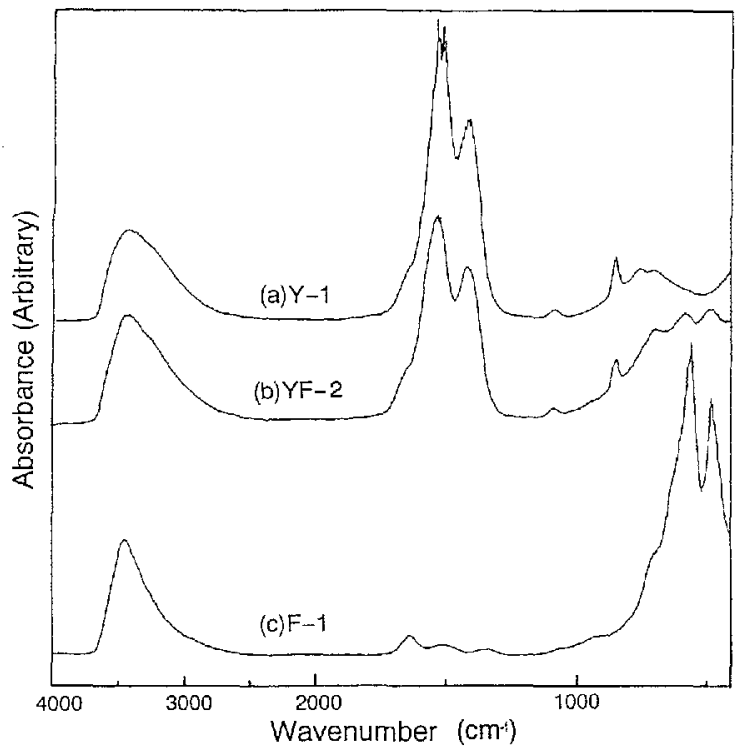

Fig. 8 IR spectra of Y-1, F-1 and YF-2.

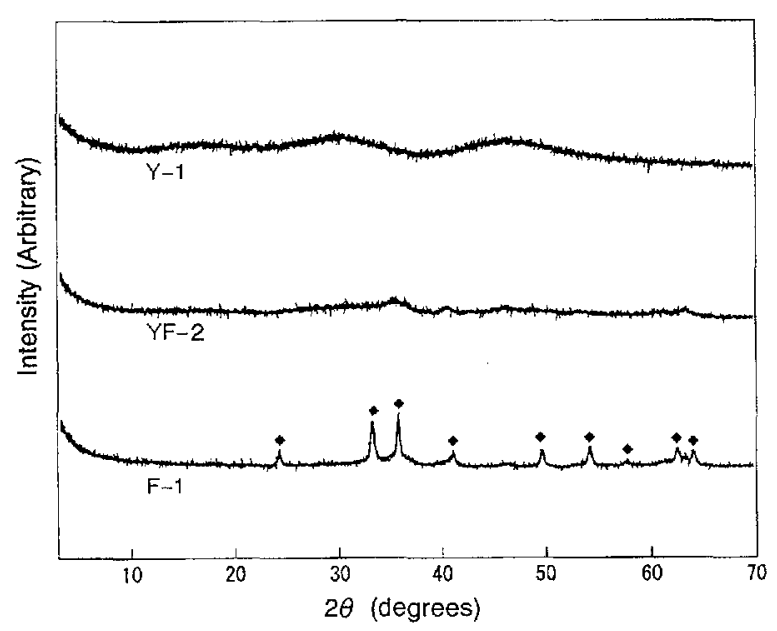

Fig. 9 X-ray diffraction patterns of Y-1, F-1 and YF-2. - : Hematite.

$3,000 \mathrm{~cm}^{-1}, \mathrm{OH} の$ 伸縮振動) が認められた 1)9)10!。一方，金属 成分として FeOみを拿むF-1 では， $\mathrm{CO}_{3}{ }^{2-}$ によると思わ机る吸 収 $\left(1,600 \sim 1,350,880 \sim 860 \mathrm{~cm}^{-1}\right)$ 注汪とんど認められず, 速赤外領域に近い呧波数領域に金属酸化物を示す吸収带が存在し た。YF-2 では，Y-1と同樣なスペクトルの傾向を示すが，Y-1 上りも $\left(1,600 \sim 1,350,880 \sim 860 \mathrm{~cm}^{-1}\right)$ での吸収が顕著でな く，また遠赤外領域に近い低波数領域に多少の吸收方認められた。 既報 ${ }^{4}$ でも諭じたように，Y 系微粒子では式(1)に示した尿素の 加水分解により水溶液中に供給される $\mathrm{CO}_{3}{ }^{2-}$ および $\mathrm{OH}^{-}$を成分 とする塩基性炭酸垍より構成されていると考元られる411)一13)。 これに対し Yを含まないF-1では，炭酸塩を構成成分としてい ないと考えられる。

Fig. 9 には，YF-2 およびY-1，F-1 で生成した微粒子のXRD パ夕ーンを示す。これら XRDパターンから，YF-2 および Y-1 では非昆筫に近い状態であると考えられる。一方，F-1では結晶 化が進んでおり，得られた XRDパターンから酸化鉄 $\left(\mathrm{Fe}_{2} \mathrm{O}_{3}\right)$

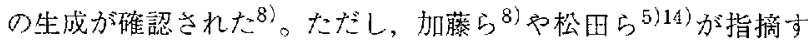
るとおり，F-1ではIR スペタトルに示された $\mathrm{OH}^{-}$を含む FeO

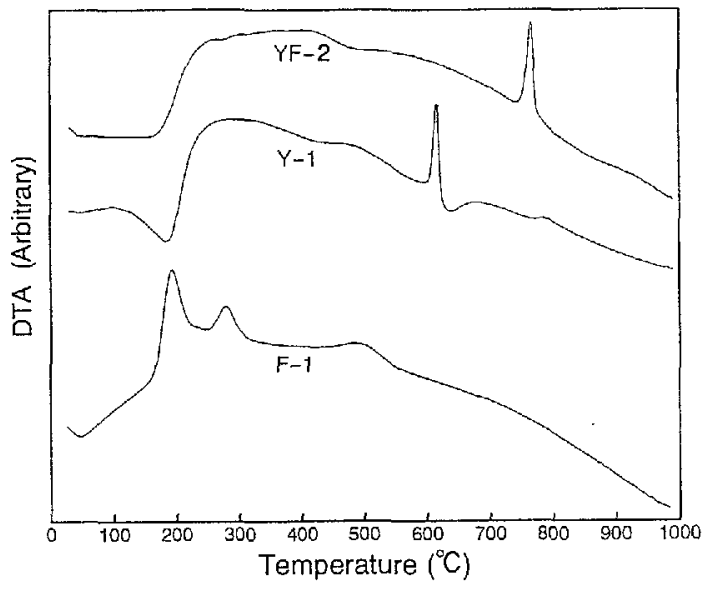

Fig. 10 DTA curves for $\mathrm{Y}-1, \mathrm{~F}-1$ and $\mathrm{YF}-2$.

$(\mathrm{OH})$ 等の化合物肪共存することも推察される。YF-6について \& YF-2 と比較して結晶化が進んで扔り，得られたXRDパ夕一 ンから $\beta-\mathrm{FeO}(\mathrm{OH})$ の生成吕推察された。

以上のXRDパターンやIR スペクトルの粘果からも，YFe系 については，Y-1やF-1 とは異なる性状にあり，単にYと Feの 各々の析出物からなる微粒子が混在している状況にはないと推察 される。3・2で述へたと扔り，粒子の大き导や形状に関しても 间様の考察が導き出されている。これらの結果から，YFe 系で は $\mathrm{Y}$ と $\mathrm{Fe}$ の各成分の含む化合物の単なる疑集体ではなく，其沈 体等のより多成分体に近い複合化した微粒子が形成されたものと 推察当れる。

\section{$3 \cdot 4$ 微粒子の焼成}

Y/Fe 比が YIG 量論比相当の YF-2で生成した微粒子と, Y-1 およびF-1 で生成した微粒子のDTA 曲楾をFig. 10に示す。金 属成分としてYのみ老含むY-1のDTA曲楾では，既報产のとお り $200{ }^{\circ} \mathrm{C}$ 前㣞で主脱水反応と考之られる吸熱反応が，600 ${ }^{\circ} \mathrm{C}$ 前後で立方晶酸化物への転化と考只られる発熱反岕か認められる。 一方，金属成分としてFeのみを含むF-1では，200 ${ }^{\circ} \mathrm{C}$ から 500

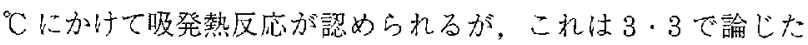
$\mathrm{OH}^{-}$を含む化合物の酸化反応ではないかと推察される ${ }^{15 !}$ ＹF-2 では，Y-1 と同栐に $200^{\circ} \mathrm{C}$ 前後で脱水反応が生じていると推察

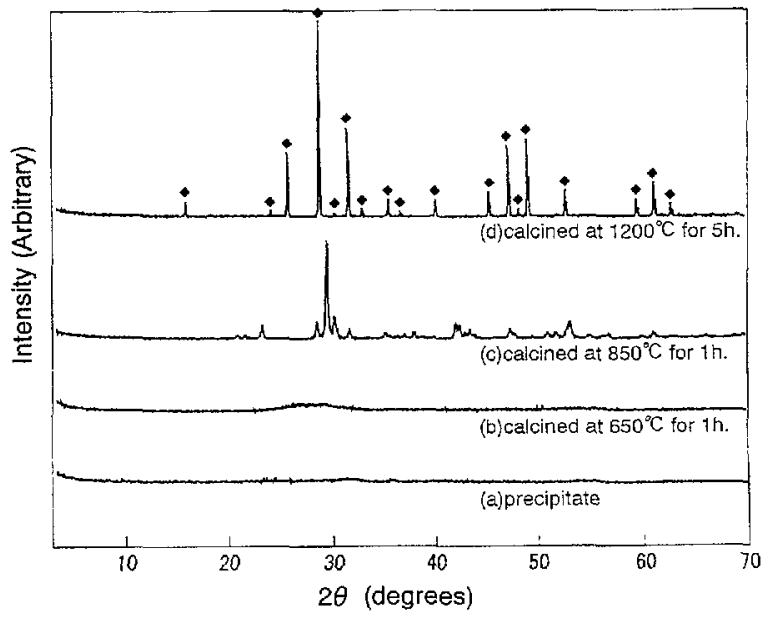

Fig. 11 X-ray diffraction patterns of YF-2; (a) YF-2 dried at room temperature; (b) calcined at $650^{\circ} \mathrm{C}$ for $1 \mathrm{~h} \mathrm{;} \mathrm{(c)}$ calcined at $850^{\circ} \mathrm{C}$ for $1 \mathrm{~h}$; (d) calcined at $1,200^{\circ} \mathrm{C}$ for $5 \mathrm{~h}$. ; YIG. 


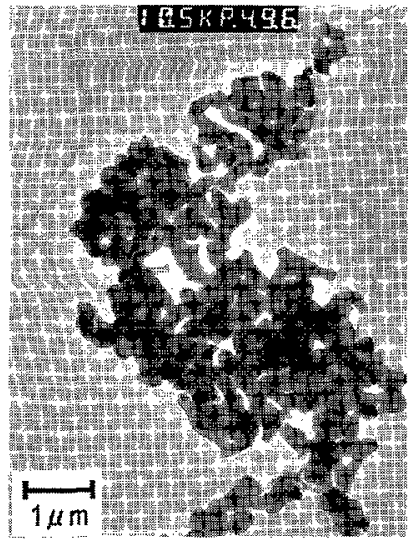

Fig. 12 The TEM photograph of YF- 8 calcined at $1,200{ }^{\circ} \mathrm{C}$ for $5 \mathrm{~h}$.

されるが，発熱のピークは $\mathrm{Y}-1$ よりも高温の $750^{\circ} \mathrm{C}$ 前瑷に認め られた。

YF-2で生成した微粒子を所定の温度で焼成した後の XRDパ 夕ーンを Fig. 11 に示す。Y柔では立方晶酸化物入転化する温度 の $650{ }^{\circ} \mathrm{C}$ での焼成では ${ }^{4)}$, 結晶化が進行しなかった。結晶化の進 行の程度に著しい変化が認められた $650^{\circ} \mathrm{C}$ と $850^{\circ} \mathrm{C}$ 間の温度域 に, DTAカーブの $750^{\circ} \mathrm{C}$ 前後の発熱ピータが位置することから, この発熱反地が結晶化の反応に相当するものと推察される。 $1,200^{\circ} \mathrm{C}$ で 5 時間焼成した場合には，850 $\mathrm{C}$ で 1 時間焼成した場

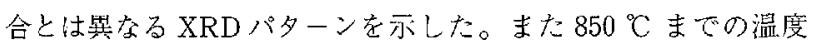
で焼成した微粒子は茶褐色索していたが，1,200 ${ }^{\circ} \mathrm{C}$ で 5 㭙間焼成 した微粒子は黄緑色となった。焼成前の微粒子は，いずれも褐色 から茶褐色であった。さらに $1,200{ }^{\circ} \mathrm{C} て ゙ 5$ 時間焼成しだ微粒子は，

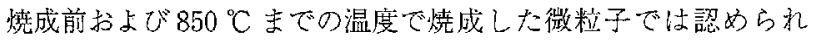
なかった頙著な磁石応答性を示した。

XRD パターンの綃果から，この $1,200{ }^{\circ} \mathrm{C}$ で 5 時間狫成して得 られた粒子は，ほば単相のYIGであることがわかった。また焼 成後の粒子は，TEM 覾察から焼成前に比べ粒子成長し大きくなっ たことがわかるが，これは一次粒子の焼結等に起因し生じたと考 えられる(Fig. 12)。以上の結果から，本法によって調製した $\mathrm{YFe}$ 系複合微粒子は，YIG の前駆体として利用可能であること がわかる。

\section{4. 結 言}

YIG 等の YFe 系化合物は, 光アイソレータや磁性材料等の機 能性材料として重要な素材である。本報では，尿素を沈殿剤発生 試薬とする均一沈殿法を用いて, 成分, 球形性や分散性意制御可 能な YFe 系の複合微粒子の調製について検討した。

実験条件としては既竬》の球状単分散微粒子が得られた $\mathrm{YEu}$ 多成分粒子合成の場合の条件を基に設定し， $\mathrm{Y} / \mathrm{Fe}$ 比や濃度等の 影響や，複合化の過程について調べた。本 $\mathrm{YFe}$ 䒺では，析出の 初期の段階で Fe 成分の加水分解等による Fe 化合物の析出反応
が主に生じ，その後尿素の加水分解の進行とともにYの析出も 生ずるようになると推察さ机る。すなわ方 $\mathrm{Y}$ と $\mathrm{Fe}$ の析出反応に は，少な加らず時間的な差が生ずると考爷られる。本実験条件下 では，60分間の反忘で $\mathrm{X}, \mathrm{Fe}$ とる析出率法 $99 \%$ 以上となり， 生成した YFe 系の微粒子は，金属成分としてYのみを含む場合， Feのみを含む場合のいずれとも異なる形態を示した。金属成分 として Feのみを含む場合の一次粒子の粒徍は $10 \mathrm{~nm}$ 以下で， $\mathrm{Y}$ のみを含む場合の粒径は $300 \mathrm{~nm}$ 程度であったが，YFe 系では 等しい条件下で粒径数十 nm 程度の微粒子が生成した。初期 $\mathrm{pH}$ が 1.5 の場合には， $\mathrm{pH} 2.3$ の場合よりも大きくサブミタロンオー ダーの四凸の著しい微粒了が生成した。原液中の尿䒺量を䂟えず 金属成分量のみ半減させて沈殿剤の相対量老增加させた場合に は，析出反応の准行がはやくなり，結果として球形性が高く大き さの揃つた微粒子が生成した。

本 $\mathrm{YFe}$ 柔の微粒子は，原液濃度により $\mathrm{Y} / \mathrm{Fe}$ 比の制御が可能 であり，XRDパターンやIR スペタトルの結果から，非晶質で 尿素の分解に起因する炭酸イオンおよび水酸化物イオン老構成成 分としてもつと推察される。 $\mathrm{Y} / \mathrm{Fe}$ 比が $\mathrm{YIG}$ 量論比相当の本微 精子を $1,200^{\circ} \mathrm{C}$ の温度で 5 時間焼成した結果, ほぼ学相の YIG が非成した。この結果から，調製した YFe 系複合微粒子が YIG の前駆体として利用可能であることがわかった。

以上，尿素を沈殿剤発生試薬として肺いた均一沈殿法により， YIG の前駆態となる Y Fe 柔復命球状微精子の調製が可能である ことを示した。

\section{引用 文 献}

1) Kobayashi, K. and Seki, M. : IEFE, J. Quantum. Electron, QE-16, p. 11, (1980)

2) Gordon, L., Salutsky, M. L. and Willard, H. H. : Precipitation from Homogeneous Solution, (1959), Wiley (New York)

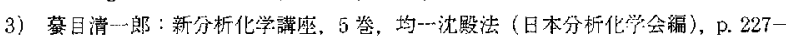
278 (1959), 共立出版 (東京); Willard, I., H, and Tang, N. K. J. Am. Chem. Soc., Vol. 59, p. 1190-1196, (1937).

4）西須佳宏.小林翰男：資源々素材，Vol. 111, p. 191-196, (1995)

5) 松田总三·香门 烸：日本化学会誌，No. 1, p. 23-27, (1983)

6) 加藤炤夫 ·陶川容子：表面科学，Vol. 8, p. 316-324，(1987)

7) Shaw, W. H. R. and Bordcaux, J. J. : J. Am. Chem. Soc., Vol. 77, p. $4729-4733,(1955)$

8) 加藤昭夫 ·森炎由紀子：日本化学会誌, No. 6, p. 800-807, (1984)

9) 羽田毦・柳谷高公・渡辺明男・白崎信一：日本さラミック協会学術喻文誌, Vol. 98 , p. 285-291, (1990)

10) Matijevic, E. and Hsu, W. P. : J. Colloid and Interface Sci., Vol. 118, p. $506-523,(1987)$

11) Aiken, B., Hso, W. P. and Matijevic, E. : J. Am. Ceram. Soc., Vol. 71, p. $845-853,(1988)$

12) Sordelet, D. and Akinc, M. : J. Colloid Iterface Sci,, Vol, 122, p. 47-59, (1988)

13)小林幹男：資源と環境, Vol. 1, p. 39-46, (1992)

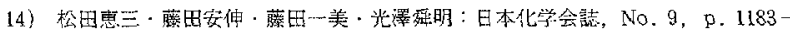
$1187,(1991)$

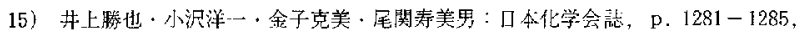
(1986) 